\title{
The Influence of Formal and Informal Education on Students' Sustainable Development Skills, a Study in Iran
}

\section{Mahtab Pouratashi*}

\begin{abstract}
This study aimed to understand the influence of formal and informal education on students' sustainable development skills. A sample of 567 students studying Humanities, Agriculture, or Engineering at public universities of Iran participated in this study. A survey was used to investigate students' skills for sustainable development according to different forms of education. Students' sustainable development skills were assessed including: empathy, participatory skill, systems-thinking, creative thinking, and anticipatory thinking. The results indicated that students had a good level of skills for sustainable development. Differences and similarities were found on students' skills by different forms of education and learning. The findings confirmed that education is useful to improve individuals' skills for sustainable development and confirmed the key role of education for sustainable development in addressing sustainable future.
\end{abstract}

Keywords: Sustainable development; formal education; informal education; skills for sustainable development; Iran

JEL Classification: $\mathrm{I} 21, \mathrm{I} 23, \mathrm{Q} 01, \mathrm{Z} 19$

\section{Introduction}

The desire to care for the environment and to sustain natural resources has grown significantly in the past decades (Alsaati et al., 2020), lead to the emergence of sustainable development concept (Cebrián \& Junyent, 2015). The current framework for sustainable development has evolved between 1972 and 1992 through a series of international conferences and meetings (Amador \& Oliveira, 2013). Sustainable development can be defined as a development that protects the environment (Klarin, 2018). It meets the needs of the present without compromising the ability of future

\footnotetext{
* Mahtab Pouratashi is at Institute for Research and Planning in Higher Education Tehran, IRAN (ISLAMIC REPUBLIC OF)
} 
generations to meet their own needs (WCED, 1987). The declaration of the UNDESD (United Nations Decade on Education for Sustainable Development) 2005-2014 was a factor for the integration of sustainability in all levels of education in the world. The definition for education for sustainable development provided by the Sustainable Development Education Panel of the United Kingdom (September 1998), stated that "Education for sustainable development enables people to develop knowledge, values and skills to participate in decisions about the way we things individually and collectively, both locally and globally, that will improve the quality of life now without damaging the planet for the future" (Abdul Aziz et al., 2012).

Governments and institutions, including institutions of higher education, are increasingly aware of the need for sustainability implementation. So, a growing number of universities and higher education institutions have adopted more responsible behavior towards society and various stakeholders increasingly pursuing sustainable development agenda (Waas et al., 2011; Nejati \& Nejati, 2013). In other words, in the path to sustainable development, formal and informal education is an essential element, and educational centers are considered as a key to dissemination of the idea of sustainable development and for creating a sustainable future. Education can change behavior and lifestyle and can be addressed as the main driver of change for sustainable development (Mulder et al., 2013). The role of education and learning for improving sustainable development emphasized by different researchers, such as:

\begin{tabular}{|l|l|}
\hline $\begin{array}{l}\text { Balakrishnan et al. } \\
(2020)\end{array}$ & $\begin{array}{l}\text { Sustainable development education in universities cultivated an appropriate sense of } \\
\text { responsibility towards sustainability among their students }\end{array}$ \\
\hline Alsaati et al. (2020) & $\begin{array}{l}\text { High percentages of participants had heard the term "sustainability" from educational } \\
\text { sources }\end{array}$ \\
\hline Tanguay et al. (2019) & $\begin{array}{l}\text { Organizations that value the acquisition of skills in sustainable development in a } \\
\text { complementary way stand out as the most active in their approach to sustainable } \\
\text { development }\end{array}$ \\
\hline Eizaguirre et al. (2019) & $\begin{array}{l}\text { The role of higher education is essential for providing future professionals with the } \\
\text { necessary profiles to respond to the sustainability challenges in increasingly complex } \\
\text { and global contexts }\end{array}$ \\
\hline Piza et al. (2018) & $\begin{array}{l}\text { universities play an essential role in providing future professionals with the necessary } \\
\text { attributes to respond to the sustainability challenges of the 21st century in increasingly } \\
\text { complex and global contexts }\end{array}$ \\
\hline $\begin{array}{l}\text { Biasutti and Frate } \\
\text { (2017) }\end{array}$ & $\begin{array}{l}\text { Education is essential for developing the necessary awareness, values, and attitudes to } \\
\text { achieve sustainable development }\end{array}$ \\
\hline $\begin{array}{l}\text { Brundiers, Wiek and } \\
\text { Redman (2010) }\end{array}$ & $\begin{array}{l}\text { key competencies such as problem-solving and collaborative skills needed for } \\
\text { sustainability }\end{array}$ \\
\hline
\end{tabular}

Higher education for sustainable development aims at enabling people to not only generate and disseminate knowledge, but also to reflect on further effects and the complexity of behavior and decisions in a global and future-oriented perspective of responsibility (Barth et al., 2007). Dyer and Selby (2004; cited in Sahin et al., 2012) 
indicated that an individual should possess the knowledge, skills, attitudes, and values required for living and working in a sustainable manner.

UNESCO (2017) in the document "Education for Sustainable Development Goals, Learning Objectives" stated that the key competencies for sustainability were: (1) systems thinking competency, (2) anticipatory competency, (3) normative competency, (4) strategic competency, (5) collaboration competency (6) critical thinking competency, and (7) self-awareness competency; and (8) integrated problem-solving competency. Different articles have made progress in conceptualizing key competencies and skills in sustainability. No agreement exists about what key skills actually are (Barth et al., 2007). Skills suggested by researchers are: systems-thinking (Sleurs, 2008; Roorda, 2010; Wiek et al., 2011; Lozano et al., 2017; Sipos et al., 2008), empathy (de Haan, 2006; Lozano et al., 2017), participatory skills (de Haan, 2006; Lozano et al., 2017), interdisciplinary work (de Haan, 2006), critical thinking (Lozano et al., 2017), anticipatory thinking (de Haan, 2006), creativity (Sipos et al., 2008), responsibility (Roorda, 2010; Lozano et al., 2017). In the present study five important skills were selected and studied, including: empathy, participatory skill, systems-thinking, creative thinking, and anticipatory thinking. Systems-thinking: is the ability to analyze complex systems across different fields (environment, society, economy, etc.) and scales (local to global) (Wiek et al., 2011). according to Torrance (1965), "Creativity is a process of sensing difficulties, problems, gaps in information, missing elements, something askew; making guesses and formulating hypothesis about these deficiencies; evaluating the testing these guesses and hypothesis; possibly revising and retesting them; and finally communicating the results" (p.8) (McCracken, 1998). Creative thinking defines as the capacity to generate many different kinds of ideas, manipulate ideas in unusual ways and make unconventional connections in order to outline novel possibilities that have the potential to elegantly meet a given purpose (Ramalingam et al., 2020). Empathy can be defined as the action of putting oneself in one's place, to understand his emotions, his thoughts in the right way (Dökmen, 2001, p.135). Empathy means to recognize others' feelings, the causes of these feelings, and to be able to participate in the emotional experience of an individual without becoming part of it (Keen, 2007). Anticipatory thinking is a critical macrocognitive function of individuals (Klein et al., 2007). Humans use anticipatory thinking to identify potential future issues and proactively take actions to manage their risks (Amos-Binks \& Dannenhauer, 2019).

Totally, the world is more complex and unsustainable and this calls for a change in lifestyle (Grecu \& Ipina, 2014). According to the aforementioned issues and since any proper planning requires the identifying the status quo, it is important to examine the level of students' knowledge and skills in sustainable development. Previous researches conducted about knowledge toward sustainable development. But there is a lack of research regarding skills for sustainable development and the effectiveness of educations on it. Also, previous existing literature is mainly influenced by researches 
conducted in developed countries, while existing works from developing countries are limited. Accordingly, this study attempted to assess the effectiveness of formal and informal education to increase students' skills for sustainable development. The current study fills the gap in the literature on sustainability in Iran. This study was guided by two objectives: (a) identifying students' skills for sustainable development; and (b) examining probable difference in skills for sustainable development according to forms of education.

\section{Material and methods}

In order to assess students' level of skills, a survey was administered to 567 university junior and senior students from selected universities of Iran. Distributional pattern of demographic information of the sampled population indicated that more than half of the respondents were female (37.2\% male and 62.8\% female). 36.7 percent of the respondents studied Humanities, 29.5 percent studied Agriculture, and 33.9 percent studied Engineering. Respondents were on average 21 years old. Most of them did not have membership in academic associations (90.7\% had membership and 9.3\% did not). 38.8 percent of respondent participated at courses in the field of sustainable development and the rest $(61.2 \%)$ did not participate at such courses. More than half of the respondents $(69.1 \%)$ participated at conferences regarding sustainable development (against 30.9\% who did not participate at such conferences).

A questionnaire, which was derived from different surveys, was administered to collect data. The questionnaire consisted of two major parts. Part 1 of the questionnaire contained questions about the respondents' general information including their gender, academic major, membership status in academic associations, participation status at courses in the field of sustainable development, and participation status at conferences regarding sustainable development. Part 2 of the questionnaire which was divided into five sections was created to examine an individual's level of skills: empathy (by 4 items), participatory skill (by 5 items), systems-thinking (by 10 items), creative thinking (by 10 items), and anticipatory thinking (by 12 items). The respondents were asked to grade each of the statements on a Likert-type scale of 1 to 5 . Some statements were negatively phrased and reverse-coded to add validity to the research instrument. Face validity of the questionnaire was assessed by judgments of some faculty members. Reliability of the scales was tested by applying coefficient Cronbach's alpha. Cronbach's alpha estimates variance among the items and interrelatedness degree of items. As suggested by Netemeyer et al. (2003), the supported level of adequacy for Cronbach's alpha is at least 0.70 . Reliability of the scales was between 0.84 and 0.95 , met this criterion. Descriptive and inferential statistics (including student's t-test, F-test and Post-hoc (Duncan) test) were conducted to analyze data, using SPSS/Windows. 


\section{Results}

\section{Sustainable development skills}

As stated before, students' sustainable development skills were assessed in five skills including: empathy, participatory skill, systems-thinking, creative thinking, and anticipatory thinking. The respondents' level of empathy was 14.24 (out of 20), their level of participatory skill, systems-thinking, and creative thinking were 17.23 (out of 25), 31.75 (out of 50), and 33.95 (out of 50), respectively. Also, their level of anticipatory thinking was 42.15 (out of 60). Looking at the means, we see the means were more than the middle of scale spectrum (Table 1).

Table 1: Descriptive statistics of the variables

\begin{tabular}{|l|c|c|c|c|c|}
\hline Skill & Mean & SD & Minimum & Maximum & $\begin{array}{c}\text { middle of scale } \\
\text { spectrum }\end{array}$ \\
\hline Empathy & 14.24 & 3.37 & 5 & 20 & 12 \\
\hline Participatory skill & 17.23 & 4.28 & 6 & 23 & 15 \\
\hline systems-thinking & 31.75 & 6.48 & 13 & 47 & 30 \\
\hline Creative thinking & 33.95 & 5.62 & 12 & 48 & 30 \\
\hline Anticipatory thinking & 42.15 & 6.13 & 15 & 58 & 36 \\
\hline
\end{tabular}

Source: findings of the research

Sustainable development skills by Participation at courses in the field of sustainable development

The comparative test showed that there were significant differences between the groups (students who had attended to courses and who had not) on the basis of participatory skill, creative thinking, and anticipatory thinking; in which students who had had prior exposure to sustainability courses had significantly more level of Participatory skill $(\mathrm{p}<.01)$ and creative thinking and anticipatory thinking $(\mathrm{p}<.05)$ than the other group (Table 2). 
Table 2: Results of t-test (by participation at courses in the field of sustainable development)

\begin{tabular}{|c|c|c|c|c|c|}
\hline & Participation ... & Mean & SD & t-value & Sig. \\
\hline \multirow{2}{*}{ Empathy } & yes & 14.39 & 3.21 & \multirow{2}{*}{$0.864^{\mathrm{ns}}$} & \multirow{2}{*}{0.388} \\
\hline & no & 14.14 & 3.18 & & \\
\hline \multirow{2}{*}{ Participatory skill } & yes & 18.11 & 4.31 & \multirow{2}{*}{$2.704^{* *}$} & \multirow{2}{*}{0.007} \\
\hline & no & 16.67 & 4.27 & & \\
\hline \multirow{2}{*}{ systems-thinking } & yes & 32.25 & 6.24 & \multirow{2}{*}{$1.398^{\mathrm{ns}}$} & \multirow{2}{*}{0.163} \\
\hline & no & 31.42 & 6.32 & & \\
\hline \multirow{2}{*}{ Creative thinking } & yes & 34.82 & 5.47 & \multirow{2}{*}{$2.553^{*}$} & \multirow{2}{*}{0.012} \\
\hline & no & 33.39 & 5.38 & & \\
\hline \multirow{2}{*}{ Anticipatory thinking } & yes & 42.95 & 6.01 & \multirow{2}{*}{$2.019^{*}$} & \multirow{2}{*}{0.047} \\
\hline & no & 41.64 & 5.98 & & \\
\hline \multicolumn{6}{|l|}{$\begin{array}{l}\text { ns: Non significant } \\
* *: p<.01 \\
*: p<.05\end{array}$} \\
\hline
\end{tabular}

Source: findings of the research

Sustainable development skills by Participation at conferences regarding sustainable development

Students who had attended to conferences regarding sustainable development had more skills compared to the other group; with participatory skill and anticipatory thinking were significantly different (Table 3).

Table 3: Results of t-test (by Participation at conferences regarding sustainable development)

\begin{tabular}{|c|c|c|c|c|c|}
\hline & Participation ... & Mean & SD & t-value & Sig. \\
\hline \multirow{2}{*}{ Empathy } & yes & 14.30 & 3.14 & \multirow{2}{*}{$1.069^{\mathrm{ns}}$} & \multirow{2}{*}{0.285} \\
\hline & no & 14.11 & 2.97 & & \\
\hline \multirow{2}{*}{ Participatory skill } & yes & 17.72 & 4.18 & \multirow{2}{*}{$2.328^{*}$} & \multirow{2}{*}{0.020} \\
\hline & no & 16.13 & 4.32 & & \\
\hline \multirow{2}{*}{ systems-thinking } & yes & 31.83 & 6.52 & \multirow{2}{*}{$1.645^{\mathrm{ns}}$} & \multirow{2}{*}{0.101} \\
\hline & no & 31.57 & 6.34 & & \\
\hline \multirow{2}{*}{ Creative thinking } & yes & 33.97 & 5.68 & \multirow{2}{*}{$0.926^{\mathrm{ns}}$} & \multirow{2}{*}{0.354} \\
\hline & no & 33.90 & 5.78 & & \\
\hline \multirow{2}{*}{ Anticipatory thinking } & yes & 43.87 & 6.24 & \multirow{2}{*}{$3.012^{* *}$} & \multirow{2}{*}{0.000} \\
\hline & no & 38.30 & 6.18 & & \\
\hline \multicolumn{6}{|l|}{$\begin{array}{l}\text { ns: Non significant } \\
* *: p<.01 \\
*: p<.05\end{array}$} \\
\hline
\end{tabular}

Source: findings of the research 
Sustainable development skills by membership in academic associations

The comparative test showed that there were significant differences in empathy, participatory skill, systems-thinking, and anticipatory thinking between students who had membership in academic associations and who had not (Table 4).

Table 4: Results of t-test (by membership in academic associations)

\begin{tabular}{|c|c|c|c|c|c|}
\hline & Participation ... & Mean & SD & t-value & Sig. \\
\hline \multirow{2}{*}{ Empathy } & yes & 15.25 & 2.99 & \multirow{2}{*}{$2.167^{*}$} & \multirow{2}{*}{0.031} \\
\hline & no & 14.13 & 3.01 & & \\
\hline \multirow{2}{*}{ Participatory skill } & yes & 18.12 & 4.01 & \multirow{2}{*}{$2.638^{* *}$} & \multirow{2}{*}{0.009} \\
\hline & no & 17.13 & 4.11 & & \\
\hline \multirow{2}{*}{ systems-thinking } & yes & 34.07 & 6.23 & \multirow{2}{*}{$2.066^{*}$} & \multirow{2}{*}{0.043} \\
\hline & no & 31.51 & 6.27 & & \\
\hline \multirow{2}{*}{ Creative thinking } & yes & 35.92 & 5.47 & \multirow{2}{*}{$1.961^{\mathrm{ns}}$} & \multirow{2}{*}{0.055} \\
\hline & no & 33.74 & 5.55 & & \\
\hline \multirow{2}{*}{ Anticipatory thinking } & yes & 43.98 & 6.13 & \multirow{2}{*}{$2.248^{*}$} & \multirow{2}{*}{0.025} \\
\hline & no & 41.96 & 6.18 & & \\
\hline $\begin{array}{l}\text { ns: Non significant } \\
* *: p<.01 \\
*: p<.05\end{array}$ & & & & & \\
\hline
\end{tabular}

Source: findings of the research

\section{Sustainable development skills by academic major}

F-test of respondents' skills by academic major are demonstrated in Table 5. The results of analysis of variance revealed that there were significant differences in participatory skill and anticipatory thinking among students with different academic majors. In order to determine which means differ, Post-hoc (Duncan) test was conducted. The findings indicated that on participatory skill, there was significant difference between Humanities students and the two other groups. On anticipatory thinking, the significant difference among all the three groups was observed. 
Table 5: Results of F-test (a) and Duncan test (b)

\begin{tabular}{|c|c|c|c|c|c|c|}
\hline \multicolumn{4}{|l|}{ (a) F-test } & \multirow{2}{*}{\multicolumn{3}{|c|}{$\begin{array}{c}\text { (b) Duncan test } \\
\text { Subset for alpha }=\mathbf{0 . 0 5}\end{array}$}} \\
\hline \multirow{2}{*}{ Variable } & \multirow{2}{*}{$\mathbf{F}$} & \multirow{2}{*}{ Sig. } & \multirow{2}{*}{ Academic major } & & & \\
\hline & & & & 1 & 2 & 3 \\
\hline \multirow{3}{*}{ Empathy } & \multirow{3}{*}{$2.927^{\mathrm{ns}}$} & \multirow{3}{*}{0.061} & Engineering & 13.817 & & \\
\hline & & & Agriculture & 14.233 & & \\
\hline & & & Humanities & 14.639 & & \\
\hline \multirow{3}{*}{ Participatory skill } & \multirow{3}{*}{$3.57^{*}$} & \multirow{3}{*}{0.022} & Humanities & 16.89 & & \\
\hline & & & Engineering & & 17.24 & \\
\hline & & & Agriculture & & 17.63 & \\
\hline \multirow{3}{*}{ systems-thinking } & \multirow{3}{*}{$2.977^{\mathrm{ns}}$} & \multirow{3}{*}{0.052} & Humanities & 30.287 & & \\
\hline & & & Agriculture & 32.218 & & \\
\hline & & & Engineering & 32.927 & & \\
\hline \multirow{3}{*}{ Creative thinking } & \multirow{3}{*}{$1.239^{\mathrm{ns}}$} & \multirow{3}{*}{0.290} & Agriculture & 33.485 & & \\
\hline & & & Engineering & 33.838 & & \\
\hline & & & Humanities & 34.432 & & \\
\hline \multirow{3}{*}{ Anticipatory thinking } & \multirow{3}{*}{$6.820^{* *}$} & \multirow{3}{*}{0.004} & Agriculture & 40.503 & & \\
\hline & & & Engineering & & 42.114 & \\
\hline & & & Humanities & & & 43.51 \\
\hline $\begin{array}{l}\mathrm{ns}: \text { Non significant } \\
* *: p<.01 \\
*: p<.05 \\
\end{array}$ & & & & & & \\
\hline
\end{tabular}

Source: findings of the research

\section{Discussion}

Education is used as a tool to achieve sustainability and the important role of education and learning as tools for achieving change and sustainable development emphasized by researchers such as Glover and Peters (2013) and Mochizuki and Fadeeva (2010). In Iran, formal and informal education offered to students regarding sustainable development. But there is a lack of research regarding the effectiveness of these educations. Accordingly, this study attempted to assess the effectiveness of education to increase students' skills for sustainable development. One objective of our study was to examine level of students' skills for sustainable development. The findings revealed that respondents' level for all the studied skills (empathy, participatory skill, systems-thinking, creative thinking, and anticipatory thinking) were favorable and more than the middle of scale spectrum. The findings of comparative analyses showed differences and similarities on students' skills. The study confirmed that courses in the field of sustainable development and conferences regarding sus- 
tainable development had positive influence on their participants and there were significant differences between skills for sustainable development of students who had participated in these activities and those who had not participated. Therefore, it is recommended that universities as a motor for change offer sustainable development courses for all students. Education is the key to change behavior and lifestyle and is addressed as the main driver of change for sustainable development (Mulder et al., 2013). Higher education institutions can make a significant impact in the advancement of sustainable development. Hence, in order to have lasting future, higher education institutions must equip students with knowledge and skills toward sustainable development, so that they can set their life goals in a way that provides sustainable prosperity for present generation and a better planet for future generations.

Our study showed that academic major had significant effect on skills for sustainable development. Therefore, it is recommended that universities revise the content of general and specialized courses to promote the integration of socio-economic and environmental categories of sustainable development. It is recommended that academic education be transformed from a traditional one and move towards interdisciplinary approaches. It is recommended that more scientific conferences in topics related to sustainable development be held and experts be invited to give a lecture. It is recommended that Universities take the lead in the development of new forms of interdisciplinary curriculum and education that is proposing solutions for challenges related to sustainable development. According to the results, membership in academic associations has positive effect on skills for sustainable development. So, it is recommended that universities support from academic and scientific associations in the field of sustainable development. In addition, students be encouraged for membership and actively participation in this associations. It is recommended that effective communication between the university and the industry for pursuing sustainable activities be established.

The results can be beneficial for universities plan activities and offer proper services that enhance students' skills for sustainable development and creating a better future for all. Also, Universities consider the impacts of their decisions and activities which are long-term and beyond the current time. Finally, it is recommended that in future studies additional researches in other countries and with a broader range of respondents be done for generalization of the results.

\section{Acknowledgements}

The authors gratefully acknowledge students who kindly participated in this study. 


\section{REFERENCES}

Abdul Aziz, A., Syed Sheikh, Sh.N., Mohd Yusof, Kh., et al. (2012). Developing a Structural Model to Assess Students' Knowledge-Attitudes towards Sustainability. Procedia-Social and Behavioral Sciences, 56, 513-522.

Alsaati, T., El-Nakla, S. \& El-Nakla, D. (2020). Level of Sustainability Awareness among University Students in the Eastern Province of Saudi Arabia. Sustainability, 12, 3159, 1-15.

Amador, F. \& Oliveira, C.P. (2013). Integrating Sustainability into the University: Past, Present, and Future. In: Caeiro et al, (eds). Sustainability Assessment Tools in Higher Education Institutions. Switzerland: Springer.

Amos-Binks, A. \& Dannenhauer, D. (2019). Anticipatory Thinking: A Metacognitive Capability. Retrieved from: arxiv.org/pdf/1906.12249.pdf

Balakrishnan, B., Tochinai, F. \& Kanemitsu, H. (2020). Perceptions and Attitudes towards Sustainable Development among Malaysian Undergraduates. International Journal of Higher Education, 9(1), 44-51.

Barth, M., Godemann,, J., Rieckmann, M. \& Stoltenberg, U. (2007). Developing key competencies for sustainable development in higher education. International Journal of Sustainability in Higher Education, 8(4), 416-430.

Biasutti, M. \& Frate, S. (2017). A validity and reliability study of the Attitudes toward Sustainable Development scale. Environmental Education Research, 23, 214-230.

Brundiers, K., Wiek, A., \& Redman, C.L. (2010). Real world learning opportunities in sustainability: From classroom into the real world, International Journal of Sustainability in Higher Education, 11(4), 308-324.

Cebrián, G. \& Junyent, M. (2015). Competencies in Education for Sustainable Development: Exploring the Student Teachers' Views. Sustainability, 7, 2768-2786.

de Haan, G. (2006). The BLK '21' programme in Germany: A 'Gestaltungskompetenz'-based model for education for sustainable development. Environmental Education Research, 1, 19-32.

Dökmen, Ü. (2001). øletiúim ÇatÕúmalarÕ ve Empati. 17. BaskÕ. østanbul: Sistem YayÕncÕIÕk.

Dyer, A., \& Selby, D. (2004). Centre of excellence for teaching and learning. Education for Sustainable Development. Stage 2 Bid, University of Plymouth, Plymouth.

Eizaguirre, A., García-Feijoo, M., \& Paul Laka, J. (2019). Defining Sustainability Core Competencies in Business and Management Studies Based on Multinational Stakeholders' Perceptions. Sustainability, 11(8), 1-21.

Glover, A. \& Peters, C. (2013). A Whole Sector Approach: Education for Sustainable Development and Global Citizenship in Wales. In: Caeiro et al, (eds). Sustainability Assessment Tools in Higher Education Institutions. Switzerland: Springer.

Grecu, V. \& Ipina, N. (2014). The Sustainable University - A model for the sustainable organization. Management of Sustainable Development, 6(2), 15-24.

Keen, S (2007). Empathy and the Novel. Oxford University Press.

Klarin, T. (2018). The Concept of Sustainable Development: From its Beginning to the Contemporary Issues. Zagreb International Review of Economics \& Business, 21(1), 67-94.

Klein, G., Snowden, D. \& Lock Pin, Ch. (2007). Anticipatory Thinking. Proceedings of the Eighth International NDM Conference (Eds. K. Mosier \& U. Fischer), Pacific Grove, CA, June 2007.

Lozano, R., Merrill, M.Y., Sammalisto, K., Ceulemans, K., \& Lozano, F.J. (2017). Connecting Competences and Pedagogical Approaches for Sustainable Development in Higher Education: A Literature Review and Framework Proposal. Sustainability, 9(10), 1889.

McCracken, Jamie L. (1998). Examining the Impact of Formal and Informal Learning on the Creativity of Women Inventors. Proceedings of the 39th Annual Adult Education Research Conference. San Antonio, Texas, May 15-16, Page 221-226. 
Mochizuki, Y., \& Fadeeva, Z. (2010). Competences for Sustainable Development and Sustainability. International Journal of Sustainability in Higher Education, 11(4), 391-403.

Mulder, K.F., Ferrer-Balas, D., Segalas-Coral, J., Kordas, O., Nikiforovich, E. \& Pereverza, K. (2013). Being scared is not enough! Motivators for Education for Sustainable Development. In: Caeiro et al, (eds). Sustainability Assessment Tools in Higher Education Institutions. Switzerland: Springer.

Nejati, M. \& Nejati, M. (2013). Assessment of sustainable university factors from the perspective of university students. Journal of Cleaner Production, 48 (2013), 101-107

Netemeyer, R.G., Bearden, W.O. \& Sharma, S. (2003). Scaling procedures: Issues and applications. Thousand Oaks, CA: Sage Publications, Inc.

Piza, V., Aparicio, J., Rodríguez, C., Marín, R., Beltrán, J., \& Bedolla, R. (2018). Sustainability in Higher Education: A Didactic Strategy for Environmental Mainstreaming. Sustainability, 10(12), 4556.

Ramalingam, D., Anderson, P., Duckworth, D., Scoular, C., \& Heard, J. (2020). Creative thinking: Definition and structure. Australian Council for Educational Research. Retrieved from: https://research.acer.edu.au/ar_misc/43

Roorda, N. (2010). Sailing on the winds of change. The Odyssey to Sustainability of the Universities of Applied Sciences in the Netherlands. PhD thesis, Maastricht University.

Sahin, E., Ertepinar, H. \& Teksoz, G. (2012). University students' behaviors pertaining to sustainability: A structural equation model with sustainability-related attributes. International Journal of Environmental \& Science Education, 7(3), 459-478.

Sipos. Y., Battisti, B., \& Grimm, K. (2008). Achieving transformative sustainability learning: engaging heads, hands and heart. International Journal of Sustainability in Higher Education, 9(1), $68-86$

Sleurs, W. (ed.), (2008). Competences for ESD (Education for Sustainable Development) teachers. A framework to integrate ESD in the curriculum of teacher training institutes, Brussels.

Tanguay, G., Berthold, E. \& Boivin, M. (2019). Learning and Skills for Sustainable Development: Academic or Organizational Training? Scientific Series, Montréal.

UNESCO. (2017). Education for Sustainable Development Goals: Learning Objectives; UNESCO: Paris, France. Retrieved from: http://unesdoc.unesco.org/images/0024/002474/247444e.pdf

Waas, T., Hugé, J., Verbruggen, A., \& Wright, T., (2011). Sustainable development: a Bird's Eye view. Sustainability, 3, 1637-1661.

WCED (World Commission on Environment and Development). (1987). Our common future. Oxford: Oxford University Press.

Wiek, A., Withycombe, L., \& Redman, C.L. (2011). Key Competencies in Sustainability: A Reference Framework for Academic Program Development. Sustainability Science, 6, 203-218. 